Article

\title{
Conversion of Starchy Waste Streams into Polyhydroxyalkanoates Using Cupriavidus necator DSM 545
}

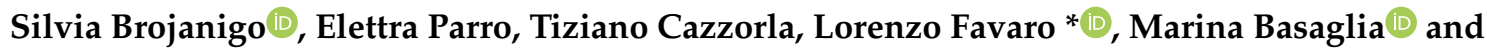 \\ Sergio Casella
}

Department of Agronomy, Food, Natural Resources, Animals and Environment (DAFNAE), University of Padova, Agripolis, 35020 Legnaro (PD), Italy;

silvia.brojanigo@phd.unipd.it (S.B.); elettra.parro@studenti.unipd.it (E.P.); tiziano.cazzorla@gmail.com (T.C.); marina.basaglia@unipd.it (M.B.); sergio.casella@unipd.it (S.C.)

* Correspondence: lorenzo.favaro@unipd.it; Tel.: +39-049-8272800

Received: 31 May 2020; Accepted: 30 June 2020; Published: 4 July 2020

check for updates

\begin{abstract}
Due to oil shortage and environmental problems, synthetic plastics have to be replaced by different biodegradable materials. A promising alternative could be polyhydroxyalkanoates (PHAs), and the low-cost abundant agricultural starchy by-products could be usefully converted into PHAs by properly selected and/or developed microbes. Among the widely available starchy waste streams, a variety of residues have been explored as substrates, such as broken, discolored, unripe rice and white or purple sweet potato waste. Cupriavidus necator DSM 545, a well-known producer of PHAs, was adopted in a simultaneous saccharification and fermentation (SSF) process through an optimized dosage of the commercial amylases cocktail STARGENTM 002. Broken rice was found to be the most promising carbon source with PHAs levels of up to $5.18 \mathrm{~g} / \mathrm{L}$. This research demonstrates that rice and sweet potato waste are low-cost feedstocks for PHAs production, paving the way for the processing of other starchy materials into bioplastics.
\end{abstract}

Keywords: polyhydroxyalkanoates; optimized saccharification; starchy waste; simultaneous saccharification and fermentation; low-cost carbon source; $3 \mathrm{HB}$

\section{Introduction}

Environmental problems regarding plastic pollution have increased in the last few years [1]. In Europe alone, which is the second-largest producer of fossil plastic in the world after China, its production reached 61.8 million tons in 2018 [2]. The bulk of plastic pollution is concentrated in the oceans [3], as demonstrated by the Great Pacific Garbage Patch in the Pacific Ocean. For these reasons, in order to overcome economic and environmental problems linked to plastic pollution, the research focused on the production of innovative bio-based materials such as polyhydroxyalkanoates (PHAs) [4-6]. PHAs are a family of eco-friendly polyesters which differ in their properties on the basis of their chemical composition [7-9]. Since they are thermoplastic, completely biodegradable and eco-compatible, they could be potential candidates for applications not only in the medical field [10], but also in packaging materials [11,12] and agriculture [13]. These polymers could be accumulated by different bacterial species as carbon energy storage [14-16]. Indeed, the accumulation of PHAs occur when strains grow in an unbalanced environmental condition, such as limitation of macroelements and a rich carbon source [17]. The price of PHAs is between 2.4 and $5.5 \mathrm{USD} / \mathrm{kg}$, while the cost of petroleum-based plastics ranges from 0.8 and $1.2 \mathrm{USD} / \mathrm{kg}$ [18]. Thus, PHAs substitution of conventional plastics is limited by their expensive manufacturing; in fact, the substrates alone represent up to $50 \%$ of the total production costs [13]. Traditional methods for PHAs production involve the use of expensive 
carbon sources such as pure sugars; therefore, making PHAs more competitive $[19,20]$ and searching for suitable and cheap feedstocks together with new operating strategies [21,22] are the main priorities to be addressed.

Great volumes of organic waste streams coming from agroindustry sectors are yearly available $[21,23,24]$ and could be used as a low-cost feedstocks for the production of high-value bio-products [25-31]. Recent studies indicate that it is possible to reduce the cost of PHAs manufacturing by using cheap substrates, such as waste streams from agriculture or the food industry $[5,21,24,32]$. Every year, millions of ton of rice by-products are wasted, with relevant environmental concerns [33]. According to FAOSTAT (Food and Agriculture Organization Corporate Statistical Database), about 782 million tons of rice were globally produced in 2018. Rice milling by-products could be sorted into two groups: starch-(i.e., broken, unripe and discolored rice) and lignocellulosic-rich (i.e., rice husk and rice straw) substrates [34]. Since lignocellulosic materials are the main waste of rice processing, many works are available in the literature [35-40]. However, these materials require expensive and complex pre-treatments to saccharify cellulose and hemicellulose into simple sugars before their conversion into PHAs. Focusing on starch-rich rice by-products, the worldwide availability is about 45, 30, and 7 million tons of broken, unripe and discolored rice, respectively [39]. These materials could be abundantly available as carbon sources for PHAs production with simpler pre-treatments. A small number of works report starch-rich substrates, mainly broken rice. Ugwu et al. used broken rice to feed C. necator JCM 11282 in a SSF (simultaneous saccharification and fermentation) process, but the substrate was previously liquefied with $\alpha$-amylase and $\mathrm{CaCl}_{2}$ at $50{ }^{\circ} \mathrm{C}$ for $1 \mathrm{~h}$, and a glucoamylase was then added [41]. Therefore, all these pre-treatment steps clearly increased the final PHAs production costs.

Another great amount of starchy feedstock is obtained from sweet potato processing. According to FAOSTAT, 92 million tons of sweet potatoes were produced in 2018. After industrial sweet potato processing, 23\% of the total product becomes waste. Few studies have reported the conversion of potato waste or peels into PHAs, whereas no research paper has focused yet on the pulp of sweet potato residues. For instance, Haas and colleagues applied Ralstonia eutropha NCIMB 11599 in a fed-batch reactor with saccharified potato waste resulting in high 3-hydroxybutyrate (3HB) yields [42]. Gowda and Shivakumar treated potato waste in a separated hydrolysis and fermentation (SHF) set up using Bacillus sp. as a PHAs producer [43].

C. necator DSM 545 is a well-known PHA producer, but it lacks in amylolytic activities $[20,44,45]$.

As such, starch has to be firstly hydrolyzed into glucose. Broken, discolored, unripe rice and the pulp of white and purple sweet potato by-products were then used as feedstocks in an SSF process. In the SSF process, the enzymatic hydrolysis of the starchy substrates is combined with the fermentation of the released glucose. Since the entire process occurs in a single reactor, the final costs are much lower than those of SHF, which requires more complex equipment and higher energy inputs [46]. The commercial enzymatic cocktail STARGEN ${ }^{\mathrm{TM}} 002$ was supplemented to hydrolyze starch into glucose, which can be used by C. necator DSM 545 as a carbon source. PHAs production by C. necator DSM 545 in the presence of an equivalent amount of glucose was also considered.

As such, the aim of this work is to evaluate starch-rich waste as a potential feedstock for the growth and PHAs production by C. necator DSM 545 with a low cost process. This is the first study to report the SSF conversion of discolored, unripe rice and white and purple sweet potato waste substrates into PHAs by C. necator DSM 545. Moreover, this research paper is a great platform towards the one-step processing of starchy substrates into PHAs by means of an engineered C. necator DSM 545 strain for the co-expression of $\alpha$-amylase and/or glucoamylase, which is currently under development in our laboratories. 


\section{Materials and Methods}

\subsection{Bacterial Strain and Starchy Substrates}

C. necator DSM 545 provided by DSMZ (Deutsche Sammlung von Mikroorganismen und Zellkulturen, Germany) was used in this work.

Broken, discolored and unripe rice waste was obtained from La Pila (Isola della Scala, Italy). Rice by-products were dried in a fan oven at $60^{\circ} \mathrm{C}$ for $48 \mathrm{~h}$, cooled at room temperature for $24 \mathrm{~h}$, and ground in a hammer mill with a $1.00 \mathrm{~mm}$ screen.

White and purple sweet potato pulp wastes were obtained from "Lucio Toniolo" Padova University's agricultural farm. Sweet potato pulp was frozen at $-20^{\circ} \mathrm{C}$ and lyophilized (EDWARDS Lifesciences Italia S.P.A. lyophilizer).

Dry matter content was obtained, after $48 \mathrm{~h}$, by drying the samples in triplicate in an oven at $100{ }^{\circ} \mathrm{C}$. Starchy by-products were then analyzed according to the AOAC (Association of Official Analytical Chemists, 2000) for the content in cellulose, hemicellulose, starch and lignin. Ash content was quantified by the incineration of samples at $550{ }^{\circ} \mathrm{C}$ for $4 \mathrm{~h}$. Protein content was valued using the Kjeldahl method by determining the total nitrogen, then multiplying by the 6.25 factor obtained by the nitrogen content in $100 \mathrm{~g}$ of proteins.

\subsection{Enzymatic Loading Optimization}

In order to optimize the enzymes dosage for starchy by-product saccharification, all the substrates were treated with STARGEN ${ }^{\text {TM }} 002$ (Genencor, DuPont-Danisco group, Itasca, IL, USA) at three different loading levels (low, medium and high) according to the instructions of the enzyme supplier. STARGEN ${ }^{\mathrm{TM}} 002$ has an enzymatic activity of $570 \mathrm{GAU} / \mathrm{g}$ (GAU, glucoamylase unit) and it is composed of Aspergillus kawachii $\alpha$-amylase expressed in Thricoderma reesei and T. reesei glucoamylase with a specific gravity of $1.14 \mathrm{~g} / \mathrm{mL}$.

The enzymatic saccharification was performed by adding 3\% of broken, discolored, unripe rice and white, purple sweet potato in a $250 \mathrm{~mL}$ flask which was shaken gently $(100 \mathrm{rpm})$ at $30^{\circ} \mathrm{C}$ for $96 \mathrm{~h}$ after adjusting the $\mathrm{pH}$ to 4 with $\mathrm{HCl}(1 \mathrm{M})$. Three dosages of STARGEN ${ }^{\text {тм }} 002,(1.06,1.42$, and $1.77 \mu \mathrm{L}$ per gram of starch, hereafter referred to as low, medium, and high enzyme loading) were evaluated. Samples were withdrawn after $0,12,24,36,48,60,72$, and $96 \mathrm{~h}$, heat-denatured (boiled for $10 \mathrm{~min}$ ) to inactivate the enzymes, then kept at $-20{ }^{\circ} \mathrm{C}$ until HPLC (high performance liquid chromatography) analysis.

To calculate the degree of saccharification (DS) of starch, the concentration of glucose available before saccharification was considered.

$$
D S_{\text {starch }}=\frac{[\text { glucose } g / L] \times 0.9}{[\text { starch } g / L]} \times 100 \%
$$

$D S_{\text {starch }}$ was calculated considering the concentration of the total sugar released during hydrolysis when compared to the initial content of starch in the substrates. Since during hydrolysis a water molecule was added, a conversion factor of $0.9(162 / 180)$ was applied due to the difference in the mass between glucose and the anhydroglucose ring [47].

\subsection{Scanning Electron Microscopy (SEM) Analysis}

SEM images were obtained of broken rice samples subjected to SSF by STARGEN ${ }^{\mathrm{TM}} 002$ and C. necator DSM 545. Sample preparations were resuspended in 95\% ethanol and applied to a specimen stub. Samples were then coated with gold and observed using a Jeol JSM-6490 Scanning Electron Microscope at $15 \mathrm{kV}$ [47]. 


\subsection{Culture Media and Production of PHAs from Simultaneous Saccharification and Fermentation (SSF)}

All media and starchy substrates were autoclaved at $121^{\circ} \mathrm{C}$ for $20 \mathrm{~min}$.

Cells of C. necator DSM 545 were maintained on nutrient agar (g/L: peptone 15, yeast extract 3 , $\mathrm{NaCl}$ 6, glucose 1, agar 15).

Pre-inoculum of C. necator DSM 545 was obtained in DSMZ81 medium (DSMZ, Germany) with $30 \mathrm{~g} / \mathrm{L}$ glucose in aerobically conditions, at $30^{\circ} \mathrm{C}$, under shaking (145 rpm). DSMZ81 medium contains $\mathrm{NH}_{4} \mathrm{Cl} 1 \mathrm{~g} / \mathrm{L}, \mathrm{MgSO}_{4} 7 \mathrm{H}_{2} \mathrm{O} 0.5 \mathrm{~g} / \mathrm{L}, \mathrm{NaHCO}_{3} 0.5 \mathrm{~g} / \mathrm{L}, \mathrm{KH}_{2} \mathrm{PO}_{4} 2.3 \mathrm{~g} / \mathrm{L}, \mathrm{Na}_{2} \mathrm{HPO}_{4} 7 \mathrm{H}_{2} \mathrm{O} 2.9 \mathrm{~g} / \mathrm{L}$, $\mathrm{CaCl}_{2} 2 \mathrm{H}_{2} \mathrm{O} 0.01 \mathrm{~g} / \mathrm{L}$, ferric ammonium citrate $0.05 \mathrm{~g} / \mathrm{L}$ and standard vitamin solution, which contains the following: riboflavin $0.0005 \mathrm{mg}$; thiamine- $\mathrm{HCl} \cdot 2 \mathrm{H}_{2} \mathrm{O} 0.0025 \mathrm{mg}$; nicotinic acid $0.0025 \mathrm{mg}$; pyridoxine- $\mathrm{HCl} 0.0025 \mathrm{mg}$; Ca-pantothenate $0.0025 \mathrm{mg}$; biotin $0.000005 \mathrm{mg}$; folic acid $0.00001 \mathrm{mg}$; vitamin $\mathrm{B}_{12} 0.00005 \mathrm{mg}$. After $24 \mathrm{~h}$, cells were harvested by centrifugation ( $5500 \mathrm{rpm}$ for $15 \mathrm{~min}$ ) and washed twice with $\mathrm{NaCl} 0.9 \%$ to remove any carbon sources.

In the case of SSF experiments, cells were aerobically inoculated (initial $\mathrm{OD}_{600} \mathrm{~nm}=0.3$ ) at $30{ }^{\circ} \mathrm{C}$ under shaking (145 rpm) in a $250 \mathrm{~mL}$ flask containing $100 \mathrm{~mL}$ DSMZ81 medium and 3\% of broken, unripe, discolored rice and white and purple sweet potato individually, as the only carbon source. An optimized dosage of STARGEN ${ }^{\text {TM }} 002$ was added to promote starch hydrolysis and experiments without STARGEN ${ }^{\text {TM }} 002$ were also included for each sample. As a benchmark, an experiment with $3 \%$ glucose as a carbon source was evaluated. After 72 and $96 \mathrm{~h}$, cells were centrifuged ( $5500 \mathrm{rpm}$ for $15 \mathrm{~min}$ ) and pellets were stored at $-80^{\circ} \mathrm{C}$ before being lyophilized for PHAs analysis.

Broken rice, selected as one of the most promising substrates, was adopted also in SSF for $168 \mathrm{~h}$ and an experiment with glucose, as a benchmark, was also assessed. In this case, PHAs production was evaluated every $24 \mathrm{~h}$.

All experiments were performed in triplicate and the standard deviation is reported.

\subsection{PHAs Analysis}

PHAs concentration was determined according to Torri et al. [48] and, mainly, Braunegg et al. [49].

Samples of lyophilized cells $(10 \mathrm{~mL})$ were treated at $100{ }^{\circ} \mathrm{C}$ for $4 \mathrm{~h}$. The propyl esters of hydroxylalkanoic acids were analyzed by gas chromatography using a Thermo Finnigan Trace GC, equipped with a flame ionization detector (FID) and AT-WAX column $(30 \mathrm{~m} \times 0.25 \mathrm{~mm} \times 0.25 \mu \mathrm{m})$. The gas carrier was helium at a flow rate $1.2 \mathrm{~mL} / \mathrm{min}$ and the split/splitless injector with a split ratio of 1:30 was set at $250{ }^{\circ} \mathrm{C}$. The FID and oven temperature was set at 270 and $150{ }^{\circ} \mathrm{C}$, respectively. Benzoic acid was used as an internal standard whereas the external standards, 3-hydroxybutyric acid (3HB), poly(3-hydroxybutyric acid-co-3-hydroxyvaleric acid P(3HB-co-12 mol\% 3HV) and poly(3-hydroxybutyric acid-co-4-hydroxybytyric acid) $\mathrm{P}(3 \mathrm{HB}-\mathrm{co}-11.2 \mathrm{~mol} \% 4 \mathrm{HB})$, were purchased from Sigma-Aldrich (Italy) [50].

The results were expressed as the percentage of PHAs on cell dry biomass (CDM) or grams of PHAs/liter of culture. Selected chromatograms are available in the Supplementary Figures S1-S3.

\section{Results and Discussion}

\subsection{Starchy Waste Composition}

Rice by-products and sweet potato waste composition are reported in Table 1.

For the rice substrates tested, starch was abundant in discolored and broken rice, whereas slightly lower amounts were found in unripe rice $(68.58 \%)$. Protein is the second prominent fraction, while the content of ash, cellulose and hemicellulose are not relevant.

The starch content for sweet potato substrates was lower than that detected for rice by-products. In this case, the chemical composition reveals an amount of ash and cellulose higher than that of rice substrates, but less than $8 \%$ of protein. Lignin content was less than $1 \%$. 
Table 1. Chemical composition of rice and sweet potato waste streams used in this study.

\begin{tabular}{cccccccc}
\hline \multicolumn{1}{c}{ (\% DM) } \\
\hline Substrate & \% DM & Starch & Protein & Ash & Cellulose & Hemicellulose & Lignin \\
\hline Broken rice & 88.11 & 77.74 & 8.31 & 0.47 & 0.22 & 0.54 & - \\
Discolored rice & 87.87 & 84.61 & 8.02 & 0.50 & 0.11 & 0.90 & - \\
Unripe rice & 87.87 & 68.58 & 9.86 & 1.54 & 1.80 & 3.68 & - \\
Purple sweet potato & 33.88 & 55.79 & 7.70 & 4.51 & 3.22 & 1.65 & 0.79 \\
White sweet potato & 29.37 & 44.66 & 7.17 & 3.74 & 3.31 & 1.07 & 0.60 \\
\hline
\end{tabular}

Overall, the compositions of the tested starchy substrates are in agreement with those reported in the literature, and clearly confirmed that starch is the main polysaccharide in the selected substrates. Nunes et al. and Favaro et al. reported a starch content for broken rice of around 77\%, with proteins between $7.5-8.5 \%$ [39,51]. Yokoi et al., analyzing the chemical composition of sweet potato waste, confirm a starch content of up to $50 \%$ [52].

With the final objective to convert directly rice by-products and sweet potato waste into PHAs, C. necator DSM 545, a well-known and efficient PHAs producer, was adopted to process these waste streams into PHAs. The strain exhibited very limited biomass growth (ranging from 0.5 to $0.9 \mathrm{~g} / \mathrm{L}$ ) and PHAs production with values of up to $0.02 \mathrm{~g} / \mathrm{L}$. This finding further confirmed that $C$. necator DSM 545 lacks amylolytic enzymes [20]; thus, the SSF strategy was selected to process each starchy by-product into PHAs.

\subsection{Optimization of Enzymatic Saccharification of Starchy Substrates}

To optimize the enzymatic dose for SSF experiments, each starchy by-product was hydrolyzed by three different loadings of STARGEN ${ }^{\text {TM }}$ 002: 1.06 (low), 1.42 (medium) and 1.77 (high) $\mu \mathrm{L}$ per g of starch. As expected, the only pre-treatment in autoclave resulted in low total sugar release. When combined with enzymatic hydrolysis, the higher enzyme dose, the greater obtained saccharification yields (Figure 1).

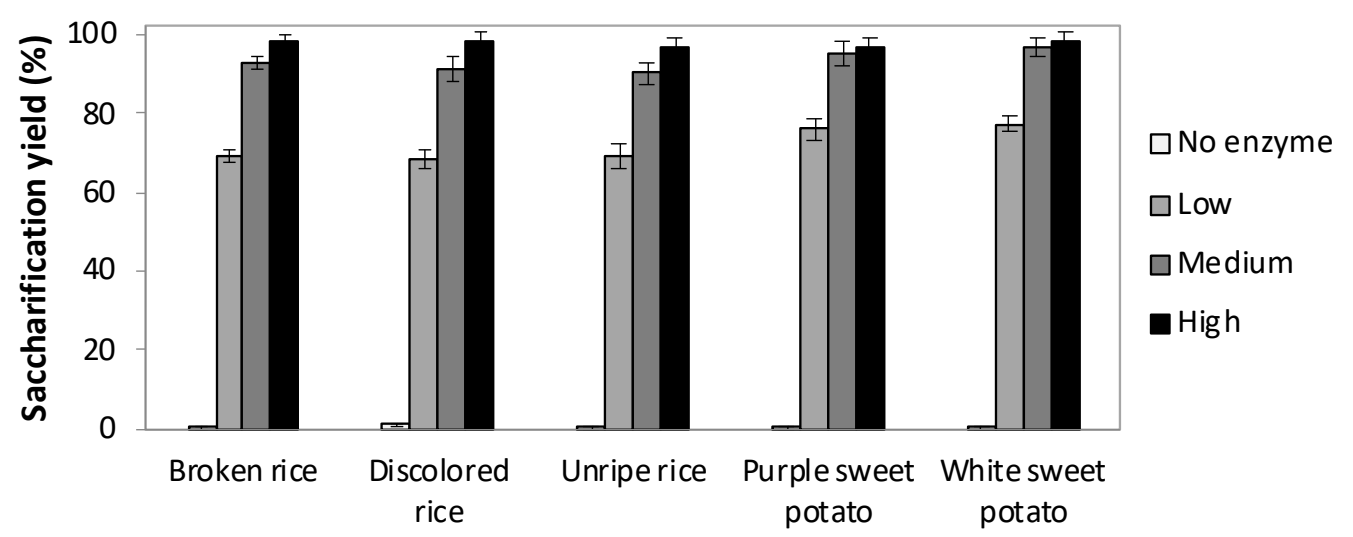

Figure 1. Saccharification yields at $96 \mathrm{~h}$ of $3 \%(w / v)$ starchy substrates with three different loadings of STARGEN ${ }^{\text {TM }}$ 002: 1.06 (low), 1.42 (medium) and 1.77 (high) $\mu \mathrm{L}$ per g of starch. Values represent the mean of three replicates and error bars represent the standard deviation.

Most of the glucose, about 75\%, was obtained within $48 \mathrm{~h}$ in all the three enzymatic loadings, with glucose levels slowly increasing up to 96 h, after which, as indicated in Figure 2, no further enzymatic hydrolysis took place. As expected, the highest glucose releases were detected with rice by-products where starch content was higher than those of sweet potato residues (Table 1). 

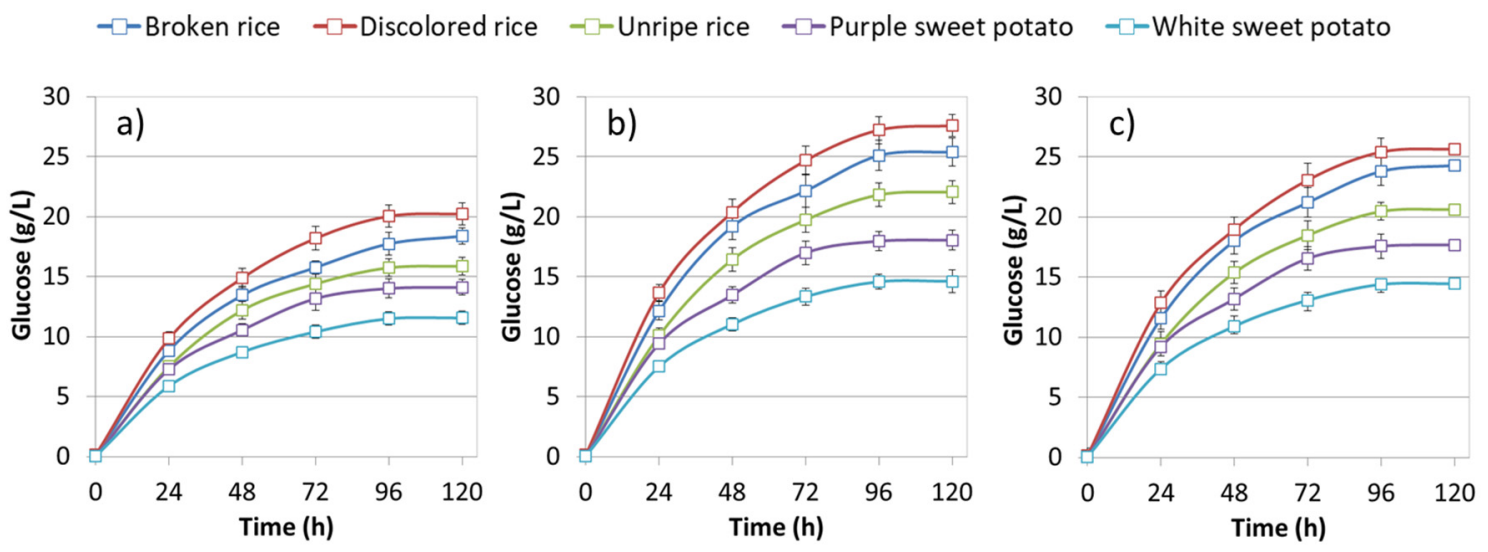

Figure 2. Glucose release $(\mathrm{g} / \mathrm{L})$ under saccharification of different starchy substrates $(3 \% w / v)$ with increasing loadings of STARGEN ${ }^{\text {TM }}$ 002: (a) 1.06 (low), (b) 1.42 (medium) and (c) 1.77 (high) $\mu \mathrm{L}$ per $\mathrm{g}$ of starch.

Within the rice by-products, slightly higher saccharification yields were obtained with the highest STARGEN ${ }^{\text {тM }} 002$ loading, whereas sweet potato residues have been efficiently saccharified by supplementing the medium dosages of $1.42 \mu \mathrm{L}$ per g of starch (Figure 1). A further increase in commercial enzymes did not result in a significantly higher glucose release (Figures 1 and 2). Since the enzyme represent a relevant cost in the entire process, the medium STARGEN ${ }^{\mathrm{TM}} 002$ loading was selected as the most efficient enzymatic dosage for SSF experiments.

\subsection{PHA Production by C. necator DSM 545 on Starch-Rich Waste}

Since one of the main objectives of the PHAs industry is to reduce the production costs, this study adopted the one-step fermentation process, known to require simpler equipment and procedures. For SSF experiments, C. necator DSM 545 was incubated in DSMZ81 broth with 3\% starch-rich material or, as a comparison, glucose. Cultures were incubated under shaking at $30^{\circ} \mathrm{C}$ and $3 \mathrm{HB}$ content was quantified after 72 and $96 \mathrm{~h}$ of incubation (Table 2).

From rice by-products, C. necator DSM 545 accumulated 3HB up to 39.51 and $44.09 \%$ of cell dry weight after 72 and $96 \mathrm{~h}$ of incubation, respectively. The comparison between $3 \mathrm{HB}$ levels from two times of incubation showed a higher yield at $96 \mathrm{~h}$ for broken and discolored rice. Instead, for unripe rice, less accumulation occurred when increasing the incubation time. This can be due to the individual chemical compositions of the different rice substrates. Indeed, unripe rice has less starch and more proteins, ashes, cellulose and hemicellulose. This result could also be due to different starch digestibility levels within the tested substrates [53]. For instance, other researchers have already described that unripe rice could resist enzymatic hydrolysis longer than well-polished rice [39,54].

The others starchy substrates processed to PHAs in this work were white and purple sweet potato waste, showing a similar chemical composition (Table 1). In this experiment, the additional incubation time to $96 \mathrm{~h}$ did not result in higher $3 \mathrm{HB}$ accumulation (Table 2). Purple sweet potato supported higher PHAs levels with $34.42 \%$ of cell dry weight. This can be due to its higher starch content as compared to that of white sweet potato (Table 1). Other studies carried out with potato waste in bioreactors report data from $55 \%$ [42] to 77\% [55] of cell dry weight, but in these experiments the hydrolysis of the potato starch to glucose was obtained before the strain inoculation. Moreover, these data are referred to as potato waste, while for sweet potato residues, data are not available in the literature for comparison.

Since glucose is the preferred substrate for the growth of PHAs and its accumulation by C. necator DSM 545 [56], the strain was also grown in DSMZ81 with 3\% glucose as a carbon source, thus producing $3 \mathrm{HB}$ up to 70 and $77 \%$ of cell dry weight with a final concentration of 4.95 and $6.60 \mathrm{~g} / \mathrm{L}$ after 72 and $96 \mathrm{~h}$, respectively (Table 2 ). 
Table 2. Production of 3-hydroxybutyrate (3HB) by C. necator DSM 545 under the simultaneous saccharification and fermentation (SSF) experiments with $3 \%$ of rice by-products or sweet potato waste and a medium dosage of STARGEN ${ }^{\mathrm{TM}} 002(1.42 \mu \mathrm{L}$ per $\mathrm{g}$ of starch). As a benchmark, an experiment with $3 \%$ of glucose was also included. The values represent the means of three replicates \pm SD.

\begin{tabular}{|c|c|c|c|c|}
\hline Substrate & $\mathrm{CDM}^{1}(\mathrm{~g} / \mathrm{L})$ & Time (h) & $3 \mathrm{HB}\left(\% \mathrm{CDM}^{1}\right)$ & $3 \mathrm{HB}(\mathrm{g} / \mathrm{L})$ \\
\hline \multirow{2}{*}{ Glucose } & $7.08 \pm 0.07$ & 72 & $70.00 \pm 0.77$ & $4.95 \pm 0.05$ \\
\hline & $8.51 \pm 0.08$ & 96 & $77.60 \pm 0.81$ & $6.60 \pm 0.07$ \\
\hline \multirow{2}{*}{ Broken rice } & $12.99 \pm 0.06$ & 72 & $39.51 \pm 0.24$ & $5.13 \pm 0.03$ \\
\hline & $13.32 \pm 0.09$ & 96 & $44.09 \pm 0.19$ & $5.18 \pm 0.02$ \\
\hline \multirow{2}{*}{ Discolored rice } & $8.87 \pm 2.17$ & 72 & $20.10 \pm 1.31$ & $1.95 \pm 0.13$ \\
\hline & $11.33 \pm 1.32$ & 96 & $31.69 \pm 1.23$ & $3.65 \pm 0.14$ \\
\hline \multirow{2}{*}{ Unripe rice } & $11.86 \pm 0.24$ & 72 & $19.39 \pm 0.35$ & $2.30 \pm 0.04$ \\
\hline & $11.29 \pm 0.16$ & 96 & $17.81 \pm 0.40$ & $2.02 \pm 0.05$ \\
\hline \multirow{2}{*}{ Purple sweet potato } & $10.86 \pm 1.75$ & 72 & $31.05 \pm 0.73$ & $3.39 \pm 0.08$ \\
\hline & $10.48 \pm 0.00$ & 96 & $34.42 \pm 0.17$ & $3.61 \pm 0.02$ \\
\hline \multirow{2}{*}{ White sweet potato } & $11.10 \pm 0.66$ & 72 & $27.67 \pm 1.11$ & $3.12 \pm 0.13$ \\
\hline & $10.51 \pm 0.24$ & 96 & $22.10 \pm 0.87$ & $2.33 \pm 0.09$ \\
\hline
\end{tabular}

${ }^{1}$ CDM: cell dry matter.

Overall, comparing all the PHAs performances obtained from rice by-products and sweet potato waste, broken rice seems to be the most promising substrate with $13.32 \mathrm{~g} / \mathrm{L}$ of cell biomass and $5.18 \mathrm{~g} / \mathrm{L}$ of $3 \mathrm{HB}$ after $96 \mathrm{~h}$.

In terms of $\mathrm{g} / \mathrm{L}$, the PHAs production by C. necator DSM 545 was indeed close to those detected from glucose. SEM reveals that, after $96 \mathrm{~h}$, the majority of starch granules contained in broken rice seems to be hydrolyzed by the commercial amylases. As reported in Figure 3, only few starch granules (SG) were still visible on the rice endosperm [57]. Moreover, a limited number of broken compound starch granules (BCSG) were observable with evident damages at their original polygonal structure [57]. This is in agreement with the high saccharification yields reported for broken rice in Figure 1.

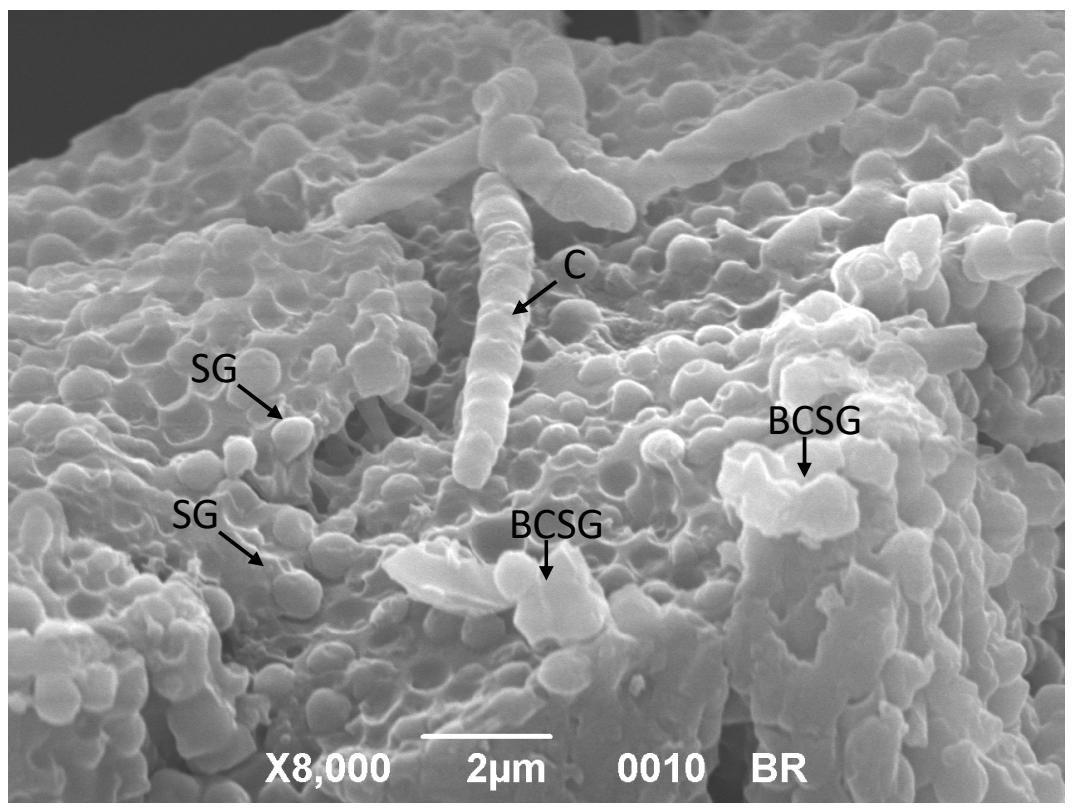

Figure 3. SEM micrograph of 3\% $w / v$ broken rice under the SSF regime with STARGEN ${ }^{\mathrm{TM}} 002$ and C. necator DSM 545. C. necator DSM 545 (C), starch granules (SG). Broken compound starch granules (BCSG), with evident damages at their original polygonal structure, are visible on rice endosperm. 
Noteworthy, the PHAs content was even higher than those reported by Ugwu et al., who obtained $38 \%$ of cell dry weight only after multiple and more complex pre-treatments [41].

Excluding unripe rice and white sweet potato, the prolongation of the incubation until $96 \mathrm{~h}$ during SSF increase the PHAs yield (Table 2). It is conceivable that time has a positive effect on the accumulation of PHAs, allowing the strain to transform the progressively released glucose into 3HB. Other studies confirm the direct link between time and accumulation of PHAs [58], although, prolonging the process too long causes the depletion of the carbon source and the consumption of PHAs by microorganisms for growing [59-61].

To further investigate $3 \mathrm{HB}$ production from broken rice under the SSF regime, SSF was performed for a longer incubation time (up to $168 \mathrm{~h}$ ), again in comparison with glucose as a benchmark substrate. However, as reported in Figure 4, this did not result in additional 3HB content, as both the substrates that showed similar $3 \mathrm{HB}$ yields. The glucose experiment indicates that the $3 \mathrm{HB}$ value at $96 \mathrm{~h}$ is not significantly different from those at 120 and $144 \mathrm{~h}$, while in the case of broken rice, this value seems to slightly decrease at $120 \mathrm{~h}$. It will be interesting, at a pre-industrial level, to verify why it happens and to determine if this decrease could be eliminated. For instance, since it is very difficult to control and calibrate the loading of natural heterogeneous substrates, the $\mathrm{C} / \mathrm{N}$ ratio could fluctuate too much in SSF processes, and the possible action of depolymerases could take place [61].

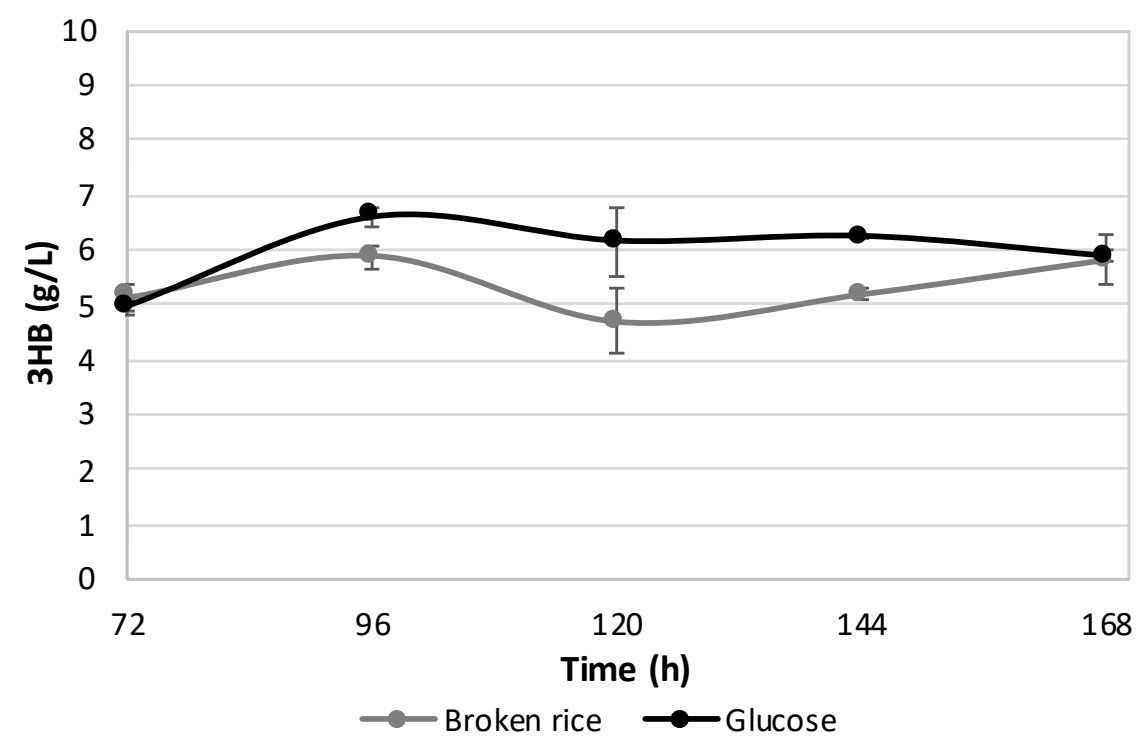

Figure 4. Levels $(\mathrm{g} / \mathrm{L})$ of $3 \mathrm{HB}$ from $3 \%$ broken rice under the SSF regime using the medium dosage of STARGEN ${ }^{\text {TM }} 002$ (1.42 $\mu \mathrm{L}$ per $g$ of starch). An experiment with glucose as a carbon source was included for comparison. The values represent the means of three replicates \pm SD.

As such, the incubation time of $96 \mathrm{~h}$ was found to be the most suitable to support PHAs production from broken rice and longer incubations, while increasing the total production costs, did not result in additional and significantly higher PHAs contents.

\section{Conclusions}

This study demonstrates that, in a SSF procedure, starchy by-products could be processed as potential carbon sources to grow and produce PHAs by C. necator DSM 545. Thus, the substrates were efficiently hydrolyzed by optimized dosages of enzymes and then converted into PHAs. Broken rice was found to be the most promising substrate with a $3 \mathrm{HB}$ yield of up to $5.18 \mathrm{~g} / \mathrm{L}$. To further improve the techno-economical feasibility of the process, experiments aimed at the optimization of SSF parameters and, above all, the development of an engineered C. necator DSM 545 strain, are in progress. As such, the processing of starchy waste streams into PHAs will be a step closer towards the large-scale application. 
Supplementary Materials: The following are available online at http://www.mdpi.com/2073-4360/12/7/1496/s1, Figure S1: Gas chromatography (GC) analysis of 3-hydroxybutyric acid (3HB) methyl ester, after chloroform extraction, in dry cells of C. necator DSM 545 grown for $96 \mathrm{~h}$ in SSF of broken rice $(3 \% w / v)$ and STARGEN ${ }^{\mathrm{TM}} 002$ (1.42 $\mu \mathrm{L}$ per $\mathrm{g}$ of starch). GC analysis reveals that $3 \mathrm{HB}$ was the only polymer accumulated by C. necator DSM 545. I.S. stands for internal standard (benzoic acid). Figure S2: Gas chromatography (GC) analysis of 3-hydroxybutyric acid (3HB) methyl ester, after chloroform extraction, in dry cells of $C$. necator DSM 545 grown for $96 \mathrm{~h}$ in SSF of purple sweet potato $(3 \% w / v)$ and STARGEN ${ }^{\mathrm{TM}} 002(1.42 \mu \mathrm{L}$ per $\mathrm{g}$ of starch). GC analysis reveals that $3 \mathrm{HB}$ was the only polymer accumulated by C. necator DSM 545. I.S. stands for internal standard (benzoic acid). Figure S3: Gas chromatography (GC) analysis of 3-hydroxybutyric acid (3HB) methyl ester, after chloroform extraction, in dry cells of $C$. necator DSM 545 grown for $96 \mathrm{~h}$ in the presence of glucose (3\%). GC analysis reveals that $3 \mathrm{HB}$ was the only polymer accumulated by C. necator DSM 545. I.S. stands for internal standard (benzoic acid).

Author Contributions: S.B. participated in planning of the study, carried out the SSF fermentation experiments, participated in data analysis and interpretation, and drafted the manuscript. E.P. participated in planning of the study and carried out the SSF fermentation experiments. T.C. carried out the enzymatic dosages optimization. L.F. planned the study and the experimental design, participated in data analysis and interpretation, revised the manuscript and participated in funding acquisition. M.B. participated in data interpretation, commented on the manuscript and participated in funding acquisition. S.C. participated in data interpretation, commented on the manuscript and participated in funding acquisition. All authors have read and agreed to the published version of the manuscript.

Funding: This research was funded by Padova University, grant number BIRD187814/18, DOR1827441/18, DOR1824847/18 and DOR1931153/19.

Acknowledgments: The authors are grateful to Valentino Pizzocchero (University of Padova, Italy) for GC and HPLC analysis. Paolo Sambo and Carlo Nicoletto kindly provided sweet potato by-products.

Conflicts of Interest: The authors declare no conflict of interest.

\section{References}

1. Geyer, R.; Jambeck, J.R.; Law, K.L. Production, use, and fate of all plastics ever made. Sci. Adv. 2017, 3, e1700782. [CrossRef] [PubMed]

2. PlasticsEurope. Plastics-The Facts 2018. In Proceedings of the Plastic Shape the Future: The Special Show of K 2019, Dusseldorf, Germany, 16-23 October 2019.

3. Ryan, P.G.; Moore, C.J.; Van Franeker, J.A.; Moloney, C.L. Monitoring the abundance of plastic debris in the marine environment. Philos. Trans. R. Soc. B Biol. Sci. 2009, 364, 1999-2012. [CrossRef]

4. Reddy, C.S.K.; Ghai, R.R.; Kalia, V.C. Polyhydroxyalkanoates: An overview. Bioresour. Technol. 2003, 87, 137-146. [CrossRef]

5. Romanelli, M.G.; Povolo, S.; Favaro, L.; Fontana, F.; Basaglia, M.; Casella, S. Engineering Delftia acidovorans DSM39 to produce polyhydroxyalkanoates from slaughterhouse waste. Int. J. Biol. Macromol. 2014, 71, $21-27$. [CrossRef] [PubMed]

6. Khanna, S.; Srivastava, A.K. Recent advances in microbial polyhydroxyalkanoates. Process Biochem. 2005, 40, 607-619. [CrossRef]

7. Titz, M.; Kettl, K.H.; Shahzad, K.; Koller, M.; Schnitzer, H.; Narodoslawsky, M. Process optimization for efficient biomediated PHA production from animal-Based waste streams. Clean Technol. Environ. Policy 2012, 14, 495-503. [CrossRef]

8. Sudesh, K.; Abe, H.; Doi, Y. Synthesis, structure and properties of polyhydroxyalkanoates: Biological polyesters. Prog. Polym. Sci. 2000, 25, 1503-1555. [CrossRef]

9. Barham, P.J.; Keller, A.; Otun, E.L.; Holmes, P.A. Crystallization and morphology of a bacterial thermoplastic: Poly-3-Hydroxybutyrate. J. Mater. Sci. 1984, 19, 2781-2794. [CrossRef]

10. Rai, R.; Keshavarz, T.; Roether, J.A.; Boccaccini, A.R.; Roy, I. Medium chain length polyhydroxyalkanoates, promising new biomedical materials for the future. Mater. Sci. Eng. R Rep. 2011, 72, 29-47. [CrossRef]

11. Bucci, D.Z.; Tavares, L.B.B.; Sell, I. PHB packaging for the storage of food products. Polym. Test. 2005, 24, 564-571. [CrossRef]

12. Siracusa, V.; Karpova, S.; Olkhov, A.; Zhulkina, A.; Kosenko, R.; Iordanskii, A. Gas Transport Phenomena and Polymer Dynamics in PHB/PLA Blend Films as Potential Packaging Materials. Polymers 2020, $12,647$. [CrossRef] [PubMed]

13. Philip, S.; Keshavarz, T.; Akiyama, I.R. Polyhydroxyalkanoates: Biodegradable polymers with a range of applications. J. Chem. Technol. Biotechnol. 2007, 82, 233-247. [CrossRef] 
14. Penczek, S. Models of Biopolymers by Ring-Opening Polymerization; CRC Press: Boca Raton, FL, USA, 2018 ; p. 394.

15. Mozejko-Ciesielska, J.; Marciniak, P.; Szacherska, K. Polyhydroxyalkanoates synthesized by Aeromonas species: Trends and challenges. Polymers 2019, 11, 1328. [CrossRef] [PubMed]

16. Tan, G.Y.A.; Chen, C.L.; Li, L.; Ge, L.; Wang, L.; Razaad, I.M.N.; Li, Y.; Zhao, L.; Mo, Y.; Wang, J.Y. Start a research on biopolymer polyhydroxyalkanoate (PHA): A review. Polymers 2014, 6, 706-754. [CrossRef]

17. Obruca, S.; Sedlacek, P.; Koller, M.; Kucera, D.; Pernicova, I. Involvement of polyhydroxyalkanoates in stress resistance of microbial cells: Biotechnological consequences and applications. Biotechnol. Adv. 2018, 36, 856-870. [CrossRef] [PubMed]

18. Crutchik, D.; Franchi, O.; Caminos, L.; Jeison, D.; Belmonte, M.; Pedrouso, A.; Val del Rio, A.; Mosquera-Corral, A.; Campos, J.L. Polyhydroxyalkanoates (PHAs) Production: A Feasible Economic Option for the Treatment of Sewage Sludge in Municipal Wastewater Treatment Plants? Water 2020, 12, 1118. [CrossRef]

19. Akiyama, M.; Tsuge, T.; Doi, Y. Environmental life cycle comparison of polyhydroxyalkanoates produced from renewable carbon resources by bacterial fermentation. Polym. Degrad. Stab. 2003, 80, 183-194. [CrossRef]

20. Favaro, L.; Basaglia, M.; Casella, S. Improving polyhydroxyalkanoate production from inexpensive carbon sources by genetic approaches: A review. Biofuels Bioprod. BioRefin. 2019, 13, 208-227. [CrossRef]

21. Blunt, W.; Levin, D.B.; Cicek, N. Bioreactor operating strategies for improved polyhydroxyalkanoate (PHA) productivity. Polymers 2018, 10, 1197. [CrossRef]

22. Verlinden, R.A.J.; Hill, D.J.; Kenard, M.A.; Williams, C.D.; Radecka, I. Bacterial synthesis of biodegradable polyhydroxyalkanoates. J. Appl. Microbiol. 2007, 102, 1437-1449. [CrossRef]

23. Golden, M.S.; Morrison, B.; Golden, J.S. Bioeconomy numbers. BioResources 2015, 10, 4411-4440.

24. Koller, M.; Maršálek, L.; de Sousa Dias, M.M.; Braunegg, G. Producing microbial polyhydroxyalkanoate (PHA) biopolyesters in a sustainable manner. New Biotechnol. 2017, 37, 24-38. [CrossRef] [PubMed]

25. Obruca, S.; Marova, I.; Snajdar, O.; Mravcova, L.; Svoboda, Z. Production of poly(3-hydroxybutyrate-co-3-hydroxyvalerate) by Cupriavidus necator from waste rapeseed oil using propanol as a precursor of 3-hydroxyvalerate. Biotechnol. Lett. 2010, 32, 1925-1932. [CrossRef] [PubMed]

26. Alibardi, L.; Green, K.; Favaro, L.; Vale, P.; Soares, A.; Cartmell, E.; Bajón Fernández, Y. Performance and stability of sewage sludge digestion under $\mathrm{CO}_{2}$ enrichment: A pilot study. Bioresour. Technol. 2017, 245, 581-589. [CrossRef]

27. Scott, E.; Peter, F.; Sanders, J. Biomass in the manufacture of industrial products-the use of proteins and amino acids. Appl. Microbiol. Biotechnol. 2007, 75, 751-762. [CrossRef]

28. Shah, A.T.; Favaro, L.; Alibardi, L.; Cagnin, L.; Sandon, A.; Cossu, R.; Casella, S.; Basaglia, M. Bacillus sp. strains to produce bio-hydrogen from the organic fraction of municipal solid waste. Appl. Energy 2016, 176, 116-124. [CrossRef]

29. Myburgh, M.W.; Cripwell, R.A.; Favaro, L.; van Zyl, W.H. Application of industrial amylolytic yeast strains for the production of bioethanol from broken rice. Bioresour. Technol. 2019, 294, 122222. [CrossRef]

30. Favaro, L.; Jansen, T.; van Zyl, W.H. Exploring industrial and natural Saccharomyces cerevisiae strains for the bio-Based economy from biomass: The case of bioethanol. Crit. Rev. Biotechnol. 2019, 39, 800-816. [CrossRef]

31. Cripwell, R.A.; Favaro, L.; Viljoen-Bloom, M.; van Zyl, W.H. Consolidated bioprocessing of raw starch to ethanol by Saccharomyces cerevisiae: Achievements and challenges. Biotechnol. Adv. 2020, in press. [CrossRef]

32. Abbondanzi, F.; Biscaro, G.; Carvalho, G.; Favaro, L.; Lemos, P.; Paglione, M.; Torri, C. Fast method for the determination of short-Chain-Length polyhydroxyalkanoates (scl-PHAs) in bacterial samples by In Vial-Thermolysis (IVT). New Biotechnol. 2017, 39, 29-35. [CrossRef]

33. Abbas, A.; Ansumali, S. Global Potential of Rice Husk as a Renewable Feedstock for Ethanol Biofuel Production. Bioenergy Res. 2010, 3, 328-334. [CrossRef]

34. Wu, C.S. Preparation and Characterization of Polyhydroxyalkanoate Bioplastic-Based Green Renewable Composites from Rice Husk. J. Polym. Environ. 2014, 22, 384-392. [CrossRef]

35. Heng, K.S.; Hatti-Kaul, R.; Adam, F.; Fukui, T.; Sudesh, K. Conversion of rice husks to polyhydroxyalkanoates (PHA) via a three-Step process: Optimized alkaline pretreatment, enzymatic hydrolysis, and biosynthesis by Burkholderia cepacia USM (JCM 15050). J. Chem. Technol. Biotechnol. 2016, 92, 100-108. [CrossRef]

36. Narayanan, A.; Kumar, V.A.S.; Ramana, K.V. Production and characterization of poly (3-hydroxybutyrateco-3-hydroxyvalerate) from Bacillus mycoides DFC1 using rice husk hydrolyzate. Waste Biomass Valorization 2014, 5, 109-118. [CrossRef] 
37. Ahn, J.; Jho, E.H.; Kim, M.; Nam, K. Increased 3HV Concentration in the Bacterial Production of 3-Hydroxybutyrate (3HB) and 3-Hydroxyvalerate (3HV) Copolymer with Acid-Digested Rice Straw Waste. J. Polym. Environ. 2016, 24, 98-103. [CrossRef]

38. Ahn, J.; Jho, E.H.; Nam, K. Effect of acid-digested rice straw waste feeding methods on the $3 \mathrm{HV}$ fraction of bacterial poly(3-hydroxybutyrate-co-3-hydroxyvalerate) production. Process Biochem. 2016, 51, 2119-2126. [CrossRef]

39. Favaro, L.; Cagnin, L.; Basaglia, M.; Pizzocchero, V.; van Zyl, W.H.; Casella, S. Production of bioethanol from multiple waste streams of rice milling. Bioresour. Technol. 2017, 244, 151-159. [CrossRef]

40. Obruca, S.; Benesova, P.; Marsalek, L.; Marova, I. Use of lignocellulosic materials for PHA production. Chem. Biochem. Eng. Q. 2015, 29, 135-144. [CrossRef]

41. Ugwu, C.U.; Tokiwa, Y.; Aoyagi, H. Utilization of Broken Rice for the Production of Poly(3-hydroxybutyrate). J. Polym. Environ. 2012, 20, 254-257. [CrossRef]

42. Haas, R.; Jin, B.; Zepf, F.T. Production of poly(3-hydroxybutyrate) from waste potato starch. Biosci. Biotechnol. Biochem. 2008, 72, 253-256. [CrossRef]

43. Gowda, V.; Shivakumar, S. Agrowaste-Based Polyhydroxyalkanoate (PHA) production using hydrolytic potential of Bacillus thuringiensis IAM 12077. Braz. Arch. Biol. Technol. 2014, 57, 55-61. [CrossRef]

44. Locatelli, G.O.; Finkler, L.; Finkler, C.L.L. Orange and passion fruit wastes characterization, substrate hydrolysis and cell growth of Cupriavidus necator, as proposal to converting of residues in high value added product. Anais da Academia Brasileira de Ciências 2019, 91, e20180058. [CrossRef] [PubMed]

45. Dalsasso, R.R.; Pavan, F.A.; Bordignon, S.E.; de Aragão, G.M.F.; Poletto, P. Polyhydroxybutyrate (PHB) production by Cupriavidus necator from sugarcane vinasse and molasses as mixed substrate. Process Biochem. 2019, 85, 12-18. [CrossRef]

46. Olofsson, K.; Bertilsson, M.; Lidén, G. A short review on SSF-An interesting process option for ethanol production from lignocellulosic feedstocks. Biotechnol. Biofuels 2008, 1, 7. [CrossRef] [PubMed]

47. Cripwell, R.; Favaro, L.; Rose, S.H.; Basaglia, M.; Cagnin, L.; Casella, S.; van Zyl, W. Utilisation of wheat bran as a substrate for bioethanol production using recombinant cellulases and amylolytic yeast. Appl. Energy 2015, 160, 610-617. [CrossRef]

48. Torri, C.; Cordiani, H.; Samorì, C.; Favaro, L.; Fabbri, D. Fast procedure for the analysis of poly (hydroxyalkanoates) in bacterial cells by off-Line pyrolysis/gas-Chromatography with flame ionization detector. J. Chromatogr. A 2014, 1359, 230-236. [CrossRef]

49. Braunegg, G.; Sonnleitner, B.; Lafferty, R.M. A rapid gas chromatographic method for the determination of poly-beta-hydroxybutyric acid in microbial biomass. Appl. Microbiol. Biotechnol. 1978, 6, 29-37. [CrossRef]

50. Gamero, J.E.R.; Favaro, L.; Pizzocchero, V.; Lomolino, G.; Basaglia, M.; Casella, S. Nuclease expression in efficient polyhydroxyalkanoates-Producing bacteria could yield cost reduction during downstream processing. Bioresour. Technol. 2018, 261, 176-181. [CrossRef]

51. Nunes, L.V.; de Barros Correa, F.F.; de Oliva Neto, P.; Mayer, C.R.M.; Escaramboni, B.; Campioni, T.S.; de Barros, N.R.; Herculano, R.D.; Fernández Núñez, E.G. Lactic acid production from submerged fermentation of broken rice using undefined mixed culture. World J. Microbiol. Biotechnol. 2017, 33, 1-10. [CrossRef]

52. Yokoi, H.; Maki, R.; Hirose, J.; Hayashi, S. Microbial production of hydrogen from starch-Manufacturing wastes. Biomass Bioenergy 2002, 22, 389-395. [CrossRef]

53. Singh, J.; Dartois, A.; Kaur, L. Starch digestibility in food matrix: A review. Trends Food Sci. Technol. 2010, 21, 168-180. [CrossRef]

54. Englyst, K.N.; Englyst, H.N. Carbohydrate bioavailability. Br. J. Nutr. 2005, 94, 1-11. [CrossRef] [PubMed]

55. Rusendi, D.; Sheppard, J.D. Hydrolysis of potato processing waste for the production of poly- $\beta$-hydroxybutyrate. Bioresour. Technol. 1995, 54, 191-196. [CrossRef]

56. Lee, S.C.; Lee, S.Y.; Chang, H.N.; Chang, Y.K.; Woo, S.I. Poly( 3-Hydroxybutyric Acid). Biotechnol. Bioenergy 1994, 43, 892-898.

57. Kasem, S.; Waters, D.L.E.; Rice, N.F.; Shapter, F.M.; Henry, R.J. The endosperm morphology of rice and its wild relatives as observed by scanning electron microscopy. Rice 2011, 4, 12-20. [CrossRef]

58. Chen, Y.; Xu, Q.; Yang, H.; Gu, G. Effects of cell fermentation time and biomass drying strategies on the recovery of poly-3-hydroxyalkanoates from Alcaligenes eutrophus using a surfactant-chelate aqueous system. Process Biochem. 2001, 36, 773-779. [CrossRef] 
59. Xu, Y.; Wang, R.H.; Koutinas, A.A.; Webb, C. Microbial biodegradable plastic production from a wheat-based biorefining strategy. Process Biochem. 2010, 45, 153-163. [CrossRef]

60. Kedia, G.; Passanha, P.; Dinsdale, R.M.; Guwy, A.J.; Lee, M.; Esteves, S.R. Addressing the challenge of optimum polyhydroxyalkanoate harvesting: Monitoring real time process kinetics and biopolymer accumulation using dielectric spectroscopy. Bioresour. Technol. 2013, 134, 143-150. [CrossRef]

61. Povolo, S.; Basaglia, M.; Fontana, F.; Morelli, A.; Casella, S. Poly(hydroxyalkanoate) production by Cupriavidus necator from fatty waste can be ebhanched by phaZ1 inactivation. Chem. Biochem. Eng. Q. 2015, 29, 67-74. [CrossRef]

(C) 2020 by the authors. Licensee MDPI, Basel, Switzerland. This article is an open access article distributed under the terms and conditions of the Creative Commons Attribution (CC BY) license (http://creativecommons.org/licenses/by/4.0/). 